\title{
TINGKAT STRES MAHASISWA SEKOLAH TINGGI ILMU KESEHATAN YOGYAKARTA DALAM MENYUSUN SKRIPSI TAHUN AKADEMIK 2018/2019
}

\section{STRESS LEVEL OF SEKOLAH TINGGI ILMU KESEHATAN YOGYAKARTA STUDENTS IN DOING THESIS ACADEMIC YEAR 2018/2019}

\author{
Yafi Sabila Rosyad \\ Program Studi S1 Keperawatan,Sekolah Tinggi Ilmu Kesehatan Yogyakarta, Indonesia \\ Rosyad2yafi@gmail.com
}

\begin{abstract}
Abstrak
Tujuan penelitian ini untuk melihat tingkat stres mahasiswa Sekolah Tinggi Ilmu Kesehatan Yogyakarta dalam mengerjakan skripsi pada program S1 Keperawatan tahun akademik 2018/2019. Peneliti menggunakan metodologi kuantitatif dengan pendekatan deskriptif karena hanya melihat gambaran tingkat stres yang dialami mahasiswa dalam mengerjakan skripsi. Pengambilan sampel dengan cara sampling jenuh, dengan jumlah responden penelitian yang didapatkan dalam penelitian ini sebanyak 27 mahasiswa di tahun akademik 2018/2019. Dari hasil penelitian diperoleh sebagian besar responden berjenis kelamin perempuan sebesar 62,97\% dan sisanya berjenis kelamin laki-laki. Hampir seluruh responden atau 96,30\% berada pada masa remaja dan sisanya pada masa dewasa awal. Tingkat stress responden berada pada kategori normal sebanyak 59,3\%, kategori stres ringan sebesar 18,8\%, kategori sedang 11,1\%, kategori berat 7,4\%, dan sisanya dalam kategori sangat berat.
\end{abstract}

Kata Kunci ; stres, skripsi, mahasiswa keperawatan, STIKes Yogyakarta

\begin{abstract}
The purpose of this study was to look at the stress level of Nursing Undergraduete Students Sekolah Tinggi Ilmu Kesehatan Yogyakarta in working on Thesis on the 2018/2019 academic year. Researchers use quantitative methodology with a descriptive approach because it only see a picture of level stress experienced by students in doing thesis. Sampling by of saturated sample, with the number of research respondent obtained in this study as many as 27 student in the 2018/2019 academic years. This result was found that the majority of respondents were female at $62,97 \%$ and the rest were male. Almost all respondent 96,30\% were in adolescence and the rest were in early adultho0d, normal category stress level as much as 59,3\%, light category is 18,8\%, moderate stress category is $11,1 \%$, severe stress category is $7,4 \%$, and the rest in the category is very heavy.
\end{abstract}

Keywords; stress, thesis, nursing students, STIKes Yogyakarta

\section{PENDAHULUAN}

Status sebagai seorang mahasiswa dipandang lebih daripada siswa sehingga tuntutan terhadap mahasiswa menjadi lebih tinggi, salah satunya yaitu membuat tugas akhir. 
Rosyad: Tingkat stres mahasiswa ...

Menurut Bertens, (2005), mahasiswa merupakan individu yang menempuh pendidikan tinggi dalam waktu tertentu. Persepsi masyarakat terhadap mahasiswa ketika menempuh pendidikan dalam periode tertentu membuat mahasiswa memiliki berbagai tuntutan akademik yang harus diselesaikan (Wulandari, 2012). Sebagai tahap akhir di bangku perkuliahan mahasiswa dituntut untuk membuat sebuah karya tulis ilmiah.

Penyusunan skripsi merupakan salah satu cara evaluasi tahap akhir di Pendidikan Tinggi yang telah ditetapkan dan diatur dalam Peraturan Pemerintah No 30/1990 pasal 15 ayat (2) yaitu: Ujian dapat diselenggarakan melalui ujian semester, ujian akhir program studi, ujian skripsi, ujian tesis dan ujian disertasi. Pernyataan tersebut ditegaskan kembali pada pasal 16 ayat (1) yaitu ujian skripsi diadakan dalam rangka penilaian hasil belajar pada akhir studi untuk memperoleh gelar sarjana. Peraturan Pemerintah No 30/ 1990 juga mengandung pengertian bahwa penyusunan skripsi sebagai tugas akhir bukanlah syarat mutlak kelulusan namun diserahkan pihak perguruan tinggi, sehingga dapat diartikan bahwa prasyarat penyusunan skripsi adalah salah satu ciri suatu perguruan tinggi (Mordiono, 1990).

Hambatan, tantangan, dan kendala harus dihadapi oleh mahasiswa dalam menyelesaikan pendidikan tinggi salah satunya dengan mengerjakan tugas akhir. Pengelolaan waktu merupakan salah satu permasalahan yang dialami mahasiswa selama masa studi, terutama dalam masa penyelesaian studi. Hal tersebut berarti seorang mahasiswa harus mampu mengelola diri dengan berbagai cara untuk mengoptimalkan waktu yang dimiliki (Ulfa, 2010). Ada beberapa faktor yang mendasari individu melakukan penundaan dalam menyelesaikan pekerjaan yaitu faktor psikologis, motivasi, self-esteem, tingkat kecemasan, self-control dan efikasi diri (Lestariningsih, 2007; Ulfa, 2010). Salah satu faktor psikologis yang dialami mahasiswa adalah stres.

Penelitian yang dilakukan oleh Sipayung, (2016), mahasiswa yang sedang mengerjakan skripsi sebagian besar (62\%) mengalami stres tingkat tinggi. Tingkat stres sedang pada mahasiswa yang mengerjakan skripsi sebanyak 69,23\% menunjukan gejala seperti urat tegang, mudah tersinggung, produktifitas menurun, sulit membuat keputusan, dan mendiamkan orang lain (Rozaq, 2014). Stres yang dialami mahasiswa ketika sedang menyusun skripsi berakibat buruk pada kesehatan fisik, emosional, kognitif dan interpersonal pada diri mahasiswa karena mahasiswa tidak mampu mengatasi kesulitan-kesulitan yang ditemuinya selama mengerjakan skripsi (Broto, 2016; Giyarto, 2018).

Berdasarkan hasil observasi pengamatan yang dilakukan oleh peneliti terhadap enam mahasiswa keperawatan STIKes Yogyakarta yang sedang menyusun skripsi, empat 
Rosyad: Tingkat stres mahasiswa ...

mahasiswa mengatakan kurang berminat dalam hal penelitian, sulit menentukan judul penelitian, sulit mendapatkan referensi, tiga mahasiswa mengatakan merasa cemas untuk bertemu dengan dosen pembimbing, selama mengerjakan skripsi merasa lebih capek dan merasa terbebani setiap ada teman yang sudah ujian. Faktor-faktor tersebut merupakan stressor yang menyebabkan mahasiswa stres ketika mengerjakan skripsi.

Stres yang dialami mahasiswa harus dapat diselesaikan dengan cepat sehingga mahasiswa mampu menyeselaikan skripsi dengan tepat waktu. Salah satu cara yang dapat digunakan untuk mengurangi stress adalah dengan terapi progressive muscle relaxaxtion (PMR). Stres merupakan respon maladaptif dari seseorang karena mendapatkan stressor (Stuart, 2016). Stres ialah reaksi non spesifik seseorang secara psikologis, fisiologis maupun perilaku ketika mendapatkan stressor dalam kurun waktu tertentu dan tidak mampu mengatasi stressor tersebut dengan baik (Tarupolo, 2002). Stres merupakan respon seseorang karena ancaman finansial, emosional, mental dan sosial terhadap suatu perubahan di lingkungannya yang dirasakan menganggu dan mengakibatkan dirinya terancam (Anoraga, 2005). Tekanan yang dirasakan akibat tidak adanya keseimbingan antara stresor dengan kemampuan untuk mengatasinya (Indarwati, 2018).

Menurut Broto, (2016), stres pada mahasiswa yang sedang mengerjakan skripsi terjadi karena mahasiswa tidak mampu mengatasi kesulitan yang ditemui. Stres yang dialami mahasiswa berdampak secara fisik, emosional, kognitif, maupun interpersonal. Ada dua faktor penyebab stres pada mahasiswa yang sedang menyusun skripsi yaitu faktor ekstenal dan internal. Faktor internal berupa kemampuan maupun kecerdasan mahasiswa itu sendiri. Sedangkan faktor eksternal berupa tuntutan kampus, keluarga, maupun finansial (Broto, 2016). Sebelum kita memberikan intervensi untuk mengurangi tingkat stres pada mahasiswa maka, terlebih dahulu kita harus mengetahui tingkat stres yang dialami oleh mahasiswa tersebut. Salah satu cara untuk mengurangi stres adalah dengan memberikan terapi progressive muscle relaxaxtion (PMR). progressive muscle relaxaxtion (PMR) merupakann terapi relaksasi otot yang mampu mengurangi ketengangan fisik. Terapi ini menurut Lindquist, Snyeder, \& Tracy, (2014), dapat digunakan untuk mengurangi tingkat stres pada berbagai penyakit kronis. Jika mampu mengurangi tingkat stres pada penyakit kronis maka, terapi ini juga diharapkan mampu mengurangi tingkat stres pada mahasiswa yang sedang mengerjakan skripsi.

Berdasarkan penjabaran di atas peneliti ingin meneliti lebih lanjut mengenai tingkat stres mahasiswa yang sedang menyusun skripsi dengan judul "Tingkat Stres Mahasiswa Sekolah Tinggi Ilmu Kesehatan Yogyakarta dalam Penyusunan Skripsi”. 
Rosyad: Tingkat stres mahasiswa ...

\section{METODOLOGI}

Pendekatan metodologi kuantitatif dengan metode deskriptif digunakan peneliti untuk menjawab tujuan penelitian. Populasi dalam penelitian ini adalalah mahasiswa semester delapan Program S1 Keperawatan STIKes Yogyakarta sebanyak 38 orang yang sedang menempuh skripsi. Teknik pengambilan sampel yang digunakan adalah sampling jenuh karena jumlah responden yang kecil. Sampel yang didapat dalam penelitian ini sebanyak 27 responden dikarenakan beberapa mahasiswa tidak bersedia menjadi reponden, tidak memiliki akses internet, dan sedang berlibur. Penelitian ini dilakukan dari tanggal 25 Mei sampai 8 Juni 2019.

Instrumen penelitian merupakan peralatan untuk mendapatkan data sesuai dengan tujuan penelitian. Dalam penelitian ini peneliti menggunakan kuesioner baku Depression Anxiety Stress Scale 42 (DASS 42). DASS merupakan skala subjektif dibentuk untuk mengukur status emosional negatif dari depresi cemas dan stres. DAS 42 adalah suatu alat ukur yang digunakan oleh Lovibond \& Lovibond, (1995), untuk menilai serta mengetahui tingkat depresi, kecemasan dan stress yang terdiri dari 42 pertanyaan dengan menggunakan skala Likert. Alat ukur ini sudah diterima secara internasional dan sudah ada kuesioner versi bahasa Indonesia yang ditranslasikan oleh (Damanik, 2006). DASS 42 bertujuan untuk mengenal status emosional individu yang digambarkan sebagai stres.

Peneliti menggunakan alat ukur DASS 42 (stress sub scale) dengan empat belas pertanyaan. Kategori tingkat stress berdasarkan hasil ukur adalah sebagai berikut :

1. Normal jika total skor $0-14$

2. Stres ringan jika total skor $15-18$

3. Stres sedang jika total skor $19-25$

4. Stress berat jika total skor 26-33

5. Sangat berat jika total skor $>33$

Metode pengolahan data dengan menggunakan aplikasi Microsoft excel dimana, peneliti menghitung jumlah jawaban responden dan dikategorikan berdasarkan kategori diatas menurut (Lovibond \& Lovibond, 1995).

\section{HASIL DAN PEMBAHASAN}

Karakteristik mahasiswa STIKes Yogyakarta yang menjadi responden dalam penelitian ini berdasarkan jenis kelamin dan usia adalah sebagai berikut: 
Rosyad: Tingkat stres mahasiswa ...

Tabel 1 Distribusi frekuensi karakteristik mahasiswa STIKes Yogyakarta semester delapan tahun $2019(\mathrm{n}=27)$

\begin{tabular}{llcc}
\hline & f & \% \\
\hline Jenis kelamin & & \\
& Laki-laki & 10 & 37.03 \\
& Perempuan & 17 & 62.97 \\
\hline Usia & & & \\
& Remaja akhir (17-25 tahun) & 26 & 96.30 \\
& Dewasa awal (26-35 tahun) & 1 & 3.70 \\
\hline
\end{tabular}

Tabel 1 memperlihatkan distribusi frekuensi karakteristik responden dimana terdapat sebagian besar $(62,97 \%)$ responden berjenis kelamin perempuan dan sisanya berjenis kelamin laki-laki. Rentang usia responden sebagian besar berada pada rentang remaja dan sisanya berada pada rentang dewasa awal. Rentang usia responden berada pada usia remaja yaitu 1825 tahun dimana, rentang ini merupakan rentang usia remaja pertengahan dan remaja akhir (Kemenkes, 2017). Usia ini merupakan fase operasi formal karena dalam tahapan ini manusia dihadapkan dengan cara berfikir formal. Fase ini dimulai pada usia 11 tahun sampai akhir masa remaja (Kaplan, Sadock, \& Grebb, 2010). Tugas perkembangan pada usia ini adalah untuk mencapai hubungan baru yang lebih matang dengan teman sebaya, mencapai peran berdasarkan jenis kelamin, menerima perubahan fisik, menerapkan dan mencapai perilaku sosial yang bertanggung jawab, mencapai kemandirian emosional, mempersiapkan karir, mempersiapkan perkawinan dan keluarga, dan memperoleh pedoman etika sebagai pegangan hidup bermasyarakat (Hurlock, 2012).

Erikson dalam Kaplan, Sadock, \& Grebb, (2010), membagi siklus kehidupan menjadi delapan fase dimana, responden dalam penelitian ini menurut teori Erikson masuk ke dalam fase keenam (21 tahun sampai 40 tahun). Fase ini dikenal dengan istilah fase intimacy versus self-absorption or isolation. Fase ini dimulai pada saat fase remaja akhir sampai dewasa pertengah. Tugas pokok fase ini adalah mencintai dan bekerja. Mencintai memiliki arti yang sangat luas yaitu tidak hanya mencintai pasangan namun juga mencintai orang sekitar dan diri sendiri. Selain tugas mencintai/keintiman, fase ini juga merupakan fase seseorang menyiapkan masadepan yang lebih matang dan sudah memiliki pilihan bidang pekerjaan yang ditekuni. Fase ini juga sebagai fase kedewasaan kematangan berfikir walaupun pada awal fase ini masih ditemukan rasa ketidakpercayaan diri atau kebingungan peran. Pada umumnya kebingungan peran ini hanya berlaku pada masa remaja sampai ke tahap awal memasuki fase remaja akhir. Jika seseorang sudah memasuki fase awal dewasa namun 
Rosyad: Tingkat stres mahasiswa ...

seseorang itu masih mengalami kebingungan diri maka dapat mempengaruhi kemampuan kekuatan dan lama dalam menjalin hubungan keintiman.

Tabel 2 Distribusi frekuensi tingkat stres mahasiswa STIKes Yogyakarta dalam menyusun skripsi tahun 2019

\begin{tabular}{lll}
\hline Tingkat Stres & f & $\mathbf{\%}$ \\
\hline Normal & 16 & 59,3 \\
Ringan & 5 & 18,5 \\
Sedang & 3 & 11,1 \\
Berat & 2 & 7,4 \\
Sangat Berat & 1 & 3,7 \\
\hline Total & 27 & 100 \\
\hline
\end{tabular}

Tabel 2 memperlihatkan distribusi frekuensi tingkat stres mahasiswa STIKes Yogyakarta dalam menyusun skripsi tahun 2019. Tingkat stres kategori normal sebesar 59,3\% merupakan kategori terbanyak yang dialami oleh mahasiswa, tingkat stres kategori ringan sebesar $18,5 \%$, dan selebihnya dalam kategori sedang sampai sangat berat. Stres merupakan respon maladaptif dari seseorang karena mendapatkan stressor (Stuart, 2016). Stres ialah reaksi non spesifik seseorang secara psikologis, fisiologis maupun perilaku ketika mendapatkan stressor dalam kurun waktu tertentu dan tidak mampu mengatasi stressor tersebut dengan baik (Tarupolo, 2002). Stres merupakan respon seseorang karena ancaman finansial, emosional, mental dan sosial terhadap suatu perubahan di lingkungannya yang dirasakan menganggu dan mengakibatkan dirinya terancam (Anoraga, 2005). Tekanan yang dirasakan akibat tidak adanya keseimbangan antara stresor dengan kemampuan untuk mengatasinya (Indarwati, 2018). Hasil penelitian ini didukung oleh penelitian yang dilakukan Sipayung, (2016), yang mendapatkan hasil bahwa sebagian besar (62\%) mahasiswa yang sedang mengerjakan skripsi mengalami stres tinggi dan sisanya stres ringan. Dari hasil penelitian yang dilakukan oleh peneliti didapatkan hasil tingkat stres mahasiswa dari kategori normal sampai sangat berat.

Gambar 1 memperlihatkan sebaran jawaban respon responden terhadap stres. Tiga besar respon stres yang dialami responden adalah sulit beristirahat, tidak sabaran, merasa cemas, dan kesal. Hasil penelitian sejalan dengan hasil penelitian yang dilakukan oleh Indarwati, (2018), mahasiswa menunjukkan gelaja stres dengan berkeringat berlebih, mudah lelah, sulit berkonsentrasi, mudah panik, takut, dan gelisah. Stres pada mahasiswa bisa terjadi karena adanya kecemasan yang dialami dan sifat perfeksionis dalam menyelesaikan tugas (Hamblin, 2018). 


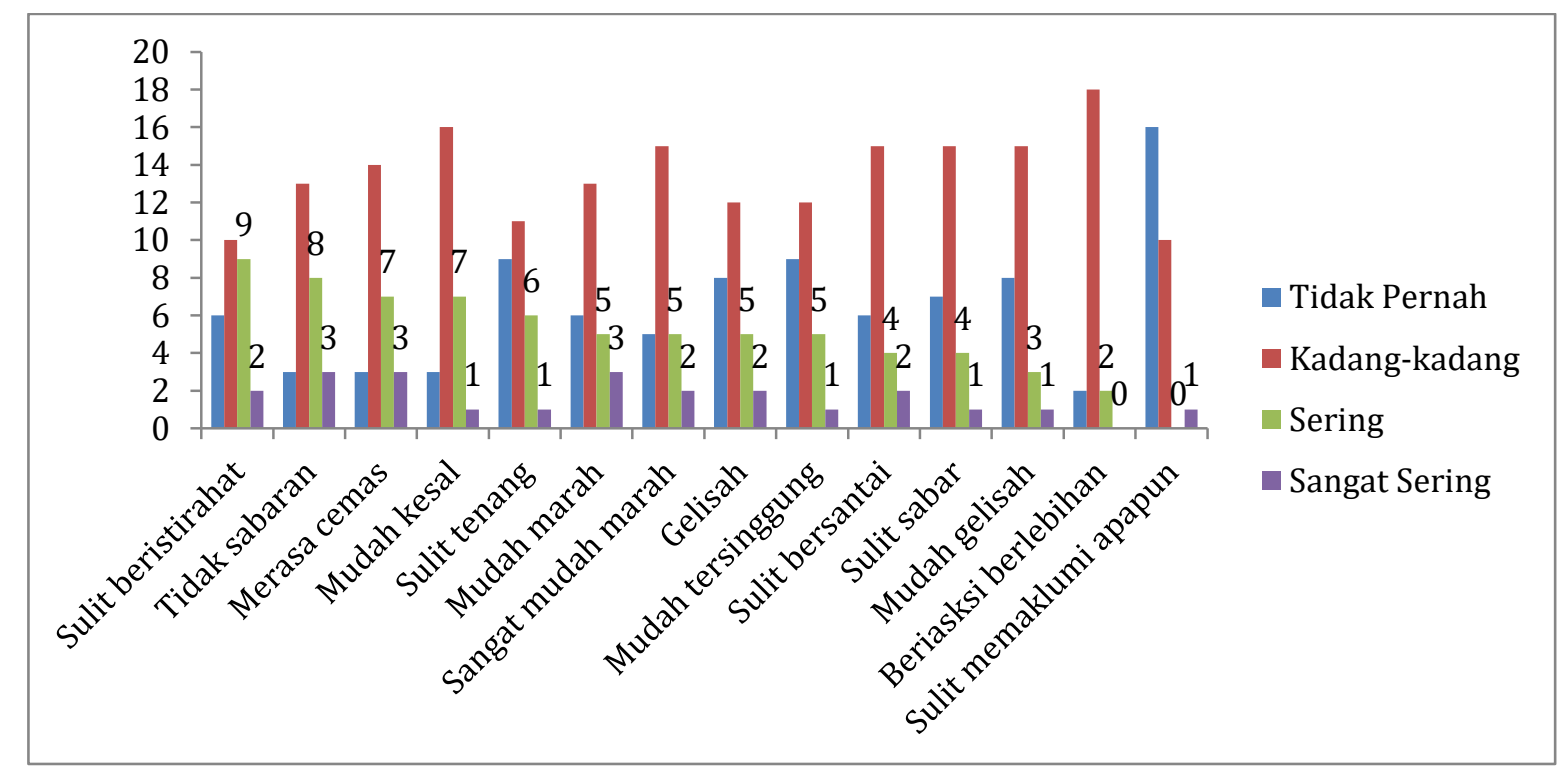

Gambar 1 Sebaran jawaban respon responden

Dari hasil penelitian di atas jelas terlihat keadaan respon psikologis mahasiswa ketika mengerjakan skripsi berupa stres dari berbagai tingkatan, baik tingkat ringan, sedang, maupun stres berat. Stres yang dialami mahasiswa harus dapat diselesaikan dengan cepat sehingga mahasiswa mampu menyeselaikan skripsi dengan tepat waktu. Salah satu cara yang dapat digunakan untuk mengurangi stress adalah dengan terapi progressive muscle relaxaxtion (PMR). Progressive muscle relaxaxtion (PMR) merupakan terapi relaksasi otot yang mampu mengurangi ketegangan fisik. Terapi ini dapat digunakan untuk memanajemen stress pada berbagai penyakit seperti Chronic Obstructive Pulmonary Diseases (COPD), Human Immunodeficiency Virus (HIV), kanker, dan lain-lain (Lindquist et al., 2014).

\section{KESIMPULAN DAN SARAN}

Sebagian besar responden $(62,97 \%)$ dalam penelitian ini berjenis kelamin perempuan dan sebanyak 96,30\% berada pada usia remaja. Sebanyak 59,3\% mahasiswa STIKes Yogyakarta yang mengerjakan skripsi tidak mengalami stres, namun sebanyak $18,6 \%$ berada pada tingkat stres ringan sebanyak $18,5 \%$ dan selebihnya pada tingkat stres sedang sampai sangat berat. Peneliti menyarankan jika sudah diketahui tingkat stres mahasiswa dalam mengerjakan skripsi maka, disarankan untuk memberikan terapi progressive muscle relaxaxtion $(P M R)$ dan agar diketahui manfaatkan terapi tersebut. 
Rosyad: Tingkat stres mahasiswa ...

\section{REFERENSI}

Anoraga, P. (2005). Psikologi Kerja. Jakarta: Rineka Cipta.

Bertens, K. (2005). Metode Belajar untuk Mahasiswa. Jakarta: Gramedia Pustaka.

Broto, H. D. F. C. (2016). Stres Pada Mahasiswa Penulis Skripsi (Studi Kasus pada Salah Satu Mahasiswa Program Studi Bimbingan dan Konseling Universitas Sanata Dharma). Universitas Sanata Dharma Yogyakarta.

Damanik, E. D. (2006). Pengujian reliabilitas, validitas, analisis item dan pembuatan norma Depression Anxiety Stress Scale (DASS): Berdasarkan kelompok sampel Yogyakaarta dan Bantul yang mengalami gemba bumi dan kelompok sampel Jakarta dan sekitarnya yang tidak mengalami gempa. Universitas Indonesia.

Giyarto. (2018). Stres pada mahasiswa tingkat akhir fakultas psikologi universitas muhammadiyah surakarta dalam mengerjakan skripsi. Universitas Muhammadiyah Surakarta.

Hamblin, E. K. (2018). Stress in College Students: Associations with Anxiety And Perfectionism. University of Mississippi.

Hurlock, E. B. (2012). Psikologi Perkembangan Suatu Pendekatan Sepanjang Rentang Kehidupan. Jakarta: Erlangga.

Indarwati. (2018). Gambaran Stres Mahasiswa Tingkat Akhir dalam Penyusunan SKRIPSI di Fakultas Kedokteran dan Ilmu Kesehatan UIN Alaudin Makasar. UIN Alauddin Makasar.

Kaplan, H., Sadock, B., \& Grebb, J. (2010). Sinopsis Psikiatri. (W. Kusuma, Ed.) (Alih Bahas). Tangerang: Binarupa Aksara.

Kemenkes. (2017). Profil Kesehatan Indonesia Tahun 2016. Jakarta: Kementerian Kesehatan RI.

Lestariningsih, W. S. (2007). Prokrastinasi Akademik Mahasiswa Ditinjau dari Efikasi Diri dan Dukungan Sosial. Universitas Muhammadiah Surakarta.

Lindquist, R., Snyeder, M., \& Tracy, M. F. (2014). Complementary \& Alternative Therapies in Nursing Seventh Edition (Seventh). New York: Springer Publishing Company, LLC.

Lovibond, S. H., \& Lovibond, P. F. (1995). Manual for the Depression Anxiety Stress Scales (2nd ed.). Sydney: Psychology Foundation.

Mordiono. Peraturan Pemerintahan Republik Indonesia Tentang Pendidikan Tinggi, Pub. L. No. Peraturan Pemerintah No 30/ 1990, 1 (1990). Indonesia. Retrieved from https://luk.staff.ugm.ac.id/atur/PP30-1990PendidikanTinggi.pdf 
Rosyad: Tingkat stres mahasiswa ...

Rozaq, A. (2014). Tingkat Stress Mahasiswa dalam Mengerjakan Skripsi. Universitas Negeri Sunan Ampel Surabaya.

Sipayung, N. (2016). Coping Stres Penulis Skripsi. Universitas Sanata Dharma.

Stuart, G. W. (2016). Prinsip dan praktik keperawatan jiwa stuart. singapura: Elsevier Inc.

Tarupolo, B. (2002). Warta Kesehatan Kerja Media Komunikasi Kesehatan Kerja Edisi 2.

Ulfa, S. H. (2010). Efikasi Diri Mahasiswa Yang Bekerja Pada Saat Penyusunan Skripsi. Universitas Muhammadiah Surakarta.

Wulandari, R. P. (2012). Hubungan Tingkat Stres dengan Gangguan Tidur pada Mahasiswa Skripsi di Salah Satu Fakultas Rumpun Science-Tekhnologi UI. Universitas Indonesia. 